Research Article

http://dx.doi.org/10.17784/mtprehabjournal.2014.12.192

\title{
The effect of manual therapy on lumbar disc protrusion.
}

\author{
○ efeito da terapia manual na protrusão discal lombar.
}

\author{
Nadielle de Macedo Rocha Paeslandim(1), Ludmilla Karen Brandão Lima de Matos(1). \\ Faculdade Integral Diferencial (FACID DEVRY), Teresina (PI), Brazil.
}

\begin{abstract}
Introduction: A herniated disc is one of the most common diagnoses among the degenerative changes of the lumbar spine. Occurs by a displacement of the nucleus pulposus through the annulus fibrosus and generally postero-lateral lying, may cause compression and irritation of the lumbar roots and dural sac, represented by clinically known as sciatica. Objective: To evaluate the effects of manual therapy on lumbar disc protrusion. Method: The study treated a longitudinal experimental research with quantitative approach. The sample was not random type, consisting of six participants. Pompage, neural mobilization, stabilization, segmental and global postural reeducation: 12 sessions, twice a week, which consisted of the following techniques were performed. Results: The data analyzed in the Graph Pad Prism 5.0 statistical program and the level of significance was $p<0,05$. In the assessment of the results of the pain Visual Analog Scale, the participants presented a significant decrease. In relation to the neural damage, there was a significant improvement of the test of elevating the leg with the extended knee, but there was not a significant improvement in the Slump Test. In the assessment of the amplitude of the flexion movement of upper body, there was a numerical gain in relation to the flexibility of the patients; however, it was not statistically significant. In the assessment of the variable paravertebral muscular strength, there was a significant improvement. In the abdominal muscular strength, there was a numerical increase; however, this value was not statistically significant. Conclusion: the treatment program with manual techniques used in this present research provided significant effects about the damages caused by lumbar disc protrusion.
\end{abstract}

Keywords: Herniated Disc. Physiotherapy. Low Back Pain.

\section{Resumo}

Introdução: A hérnia de disco está entre os diagnósticos mais comuns dentre as alterações degenerativas da coluna lombar. Ocorre por um deslocamento do núcleo pulposo por meio do ânulo fibroso e encontra-se geralmente póstero-lateral, podendo causar compressão e irritação das raízes lombares e do saco dural, representadas clinicamente pela dor conhecida como ciática. Objetivo: Avaliar os efeitos da terapia manual na protrusão discal lombar. Método: O estudo tratou-se de uma pesquisa experimental longitudinal com abordagem quantitativa. A amostra foi do tipo não aleatória, constituída de seis participantes. Foram realizados 12 atendimentos, duas vezes por semana, que consistiram das seguintes técnicas: pompage, mobilização neural, estabilização segmentar e reeducação postural global. Resultados: Os dados foram analisados no programa estatístico Graph Pad Prism 5.0 e o nível de significância foi p<0,05. $\mathrm{Na}$ avaliação dos resultados da Escala Visual Analógica da dor, os participantes apresentaram uma diminuição significativa. Em relação ao comprometimento neural houve melhora significativa no teste de elevação da perna com o joeIho estendido, mas não houve melhora significativa no Slump Teste. Na avaliação da amplitude de movimento de flexão do tronco houve um ganho numérico em relação à flexibilidade dos participantes, porém não foi significativo estatisticamente. No resultado da variável força muscular paravertebral ocorreu uma melhora significativa. Na força muscular abdominal houve um aumento numérico, no entanto esse valor não foi significativo estatisticamente. Conclusão: O programa de tratamento com técnicas manuais, utilizado na presente pesquisa, promoveu efeitos significativos em comprometimentos causados pela protrusão discal lombar.

Palavras-chave: Hérnia de disco. Fisioterapia. Lombalgia.

\section{Received: 30 May 2014. Accepted: 29 August 2014. Published: 8 September 2014.}

1. Physical Therapy Student, Faculdade Integral Diferencial (FACID DEVRY), Teresina (PI), Brazil.

\section{Corresponding Author:}

Nadielle de Macedo Rocha Paeslandim - Address: Quadra C, casa 22, Bela Vista III, Teresina (PI), Brazil. - Phone: (86) 8812-3394 E- mail: nadiellelsdn@hotmail.com. 


\section{INTRODUÇÃO}

A herniated disc is one of the most common diagnoses among the degenerative changes of the lumbar spine and the leading cause of surgeries. Affecting approximately $2 \%$ to $3 \%$ of the world population, with a prevalence of $4.8 \%$ in men and $2.5 \%$ in women over 35 years old.(1)

A herniated disc occurs by a displacement of the nucleus pulposus through the annulus fibrosus and generally posterolateral lying, may cause compression and irritation of the lumbar roots and dural sac, represented by clinically known as sciatica. This disc material, mainly from the nucleus pulposus, can take three different forms: Protrusion, extrusion or kidnapping. ${ }^{(2)}$

With the development of research in the area of rehabilitation, the amount of therapeutic resources for the conservative treatment of herniated disc increased, consequently, techniques involving manual therapy such as osteopathy, chiropractic, global postural reeducation, neural mobilization, the joint mobilization techniques, and other techniques such as hydrotherapy and Pilates have been included in the conservative therapy against algic and functional symptoms of the lumbar spine. (3)

Since the patient has a herniated disc in his clinical condition presents impairments such as pain, limited movement and weakness of the stabilizing muscles of the spine is necessary that the conservative treatment techniques that can intervene in these commitments are included. The pompage is a resource that can promote muscle relaxation and an improvement in flexibility and movement. (4) The technique of neural mobilization aims to impose greater stress to the nervous system, by certain postures that then directed to the peripheral nerves and the spinal cord slow, rhythmic movements are applied, providing improved conduction of nerve impulses. ${ }^{(5)}$ In patients with herniated disc, the volume of the herniated material can compress and irritate the lumbar dural sac and roots, represented clinically by sciatic pain. (2)

Another important resource, attempt to reduce lumbar pain symptoms is the training of the muscles of the lumbar spine, as these have an important function of acting in the control segment. This technique known as segmental stabilization objective to strengthen the deep torso muscles and tranverse abdomen. The concept of segmental lumbar stabilization, characterized by isometry, low intensity and timing of the deep trunk muscles, in order to stabilize the lumbar spine, protecting the structure from excessive wear. ${ }^{(7)}$

The present work had as main objective to analyze the effects of manual therapy on lumbar disc protrusion and as specific objectives measure pain in participants with lumbar disc protrusion, analyze neural involvement, assess range of motion of the trunk, check the strength of paraspinal and abdominal muscles.

\section{METHODS}

The project was submitted to Ethics Committee of FACID for review and approval in accordance with ResoIution 466/12 of the National Health Council. Upon approval under number 328/2013, all participants signed a free and informed consent and data collection was performed.

This is a longitudinal experimental research with quantitative approach.

The research was conducted in the clinic of a private college in Teresina- PI, the site was chosen because it is an environment of adequate structure and for being a clinic that receives treatment for patients with lumbar disc protrusion.

The sample was not random type, consisting of six participants. Inclusion criteria were: subjects with a diagnosis of lumbar disc protrusion confirmed by magnetic resonance imaging or computed tomography of both genders who signed the informed consent, which had to leg raising test with knee extended and the Slump test positive. Exclusion criteria were: participants who were performing other interventions for treatment of low back pain and to provide contraindication to perform the techniques.

The research was conducted from June to November of 2013. Analyzed variables before starting the program attendance were: pain, neural involvement, range of motion of the trunk, the paravertebral and abdominal strength. After each treatment, the participants were reassessed. Only the strength variable was analyzed before starting the program and after the last service call. An evaluation form was used to record the following data: name, age, height, weight, BMI, and the results of the analyzed variables.

Pain intensity was assessed by Visual Analogue Scale (VAS). Additionally, the amplitude was measured of movement in the pain that appeared in the following tests: Increase in leg with knee extended by using a goniometer of the hip; Slump test, using a goniometer knee extension; Test and third finger to the ground through the measuring tape with the distance of the third finger of the right hand to the ground.

The abdominal and paraspinal strength were measured respectively by means of the dynamic test of the abdominal resistance and dynamic resistance test extender. Were analyzed by means of values from one to five, five being the number corresponded to normal, four good, three fair, the two bad and one trace. ${ }^{(9)}$

The treatment program was conducted in 12 sessions, with a frequency of twice a week, involving the following techniques of manual therapy: pompage, neural mobilization, global postural reeducation and segmental stabilization.

The attendance began with the realization of the lumbar and piriformis pompages. Three replicates were performed, thirty seconds each pompage. In the lumbar 
pompage with participant was positioned in the prone position, put a pillow under your abdomen. The tension was obtained by removal of both hands. The pompage piriformis was performed with the participant supine, the thigh being treated was placed in $45^{\circ}$ of flexion, the knee flexed at $90^{\circ}$, supported the plan on the table with the other leg foot. The tension was obtained through a caudal traction, pulling the knee, took the hip for adduction with internal rotation.

Then the technique was performed neural mobilization. Initially three repetitions of thirty seconds with the sliding technique of lumbosacral roots in lateral recumbency and then continued treatment was through technical tensionante sciatic nerve. The slide in the lateral position, the participant stood with a towel placed above the iliac crest, oscillation was performed in the lumbar lateral bending using as leverage the pelvis. In tensionante sciatic nerve oscillations were made with the distal hand performing dorsiflexion, with the participant in the supine position, and the degree of oscillation of Maitland (II, III or IV) was chosen according to the clinical judgment of the healing phase of irritability of the research participant.

The segmental stabilization consisted of six progressive stages of exercise with isometric contraction of the transverse muscles of the abdomen, multifidus and pelvic floor. Each step was performed on each week of care. Each exercise was performed in 12 repetitions while maintaining the contraction for 10 seconds.

In the first stage the exercise was held without charge, without balance, and static. The participant was in a supine position with knees flexed adducted promoting activation of the transversus abdominis and prone with knees straight, arms along the body, promoting the activation of the multifidus muscle.

In the second stage the exercise was carried without charge, without balance, but with movement. The participant was in a supine position with flexed knees performing the heel slip on the stretcher, then on the same decubitus performed unilateral increase of the upper limb and lower limb contralateral flexion.

In the third stage the exercise was performed without charge with movement and balance. The participant performed the movement of bridge with your feet flat on the stretcher and knees flexed, raising the pelvis and holding the contraction of the deep muscles of the trunk. Cat position in the participant performed alternating movement of the upper diagonal (flexion) and lower (extension) members.

In the fourth stage the exercises were done without moving, without balance, but under load, the participant sitting pelvic performed bearing (Prancing glutes without prance the chest) with contraction of the deep muscles of the trunk. Standing, was static form (no movement) performing the contraction of transversus abdominis and multifidus.
The fifth and sixth steps were marked by more intense workouts. All the muscles of the spinal column was enabled, promoting greater stability. In the exercise of unilateral pelvic lift bridge performed associated with the elevation of the lower limb in extension, with the contraction of the transversus abdominis and multifidus; in the exercise of lateral bridge in the lateral decubitus participant performed side elevation of the pelvis with support feet and elbow keeping the contraction of transversus abdominis and multifidus. During the board with the participant prone performed to lift the pelvis to support the feet and elbows, keeping the contraction of transversus abdominis and multifidus.

Posture on sloping foot forward the GPR was the participant with the feet positioned with heels together forefoot away at an angle of $30^{\circ}$, with the trunk inclined previously, in a range that did not cause pain and hand support on the stretcher. This was removed with continued treatment. During the progression of stance in treatment the participant was instructed to keep the spine in growth, lean the trunk above, perform antiversão pelvis and slowly extend your knees. During the technical, verbal commands and hand contacts were used to request the maintenance of spinal alignment and breathing was requested with prolonged expirations. The total time technique was set to 15 minutes carried out in triplicates with five minutes.

Once collected, the data were organized into spreadsheets Microsoft Office Excel 2010 program for creating table. Later, the data were transferred to the statistical program Graph Pad Prism 5.0 for analysis of variance when the one-way ANOVA and post hoc Tukey test 95\% and significance level of $p<0.05$ was applied.

\section{RESULTS}

Analyzing the mean and standard deviation of age, weight, height and BMI sample of this research was homogeneous (Table 1).

The visual analog scale was used in each care for pain assessment. Testing one-way ANOVA and post hoc Tukey test CI 95\% showed that there was a significant decrease in pain $(p<0.01)$ from the seventh session ( $\mathrm{Fi}-$ gure 1 ). This value was compared with the initial value before starting the treatment. Comparing the amount of pain on the initial assessment and the last day of service was also meant the difference $(p<0.001)$.

Table 1. Anthropometric data.

\begin{tabular}{lcc}
\hline Variable & Average & $* *$ SD \\
\hline Age & 36.66 & \pm 8.31 \\
Weight $(\mathrm{Kg})$ & 60.83 & \pm 13.88 \\
Height $(\mathrm{m})$ & 1.57 & \pm 0.09 \\
*BMI $\left(\mathrm{Kg} / \mathrm{m}^{2}\right)$ & 24.27 & \pm 2.86 \\
\hline *IMC: Body mass index.**SD: Standard Deviation &
\end{tabular}


The evaluation of the neural damage through the range of motion of the hip assessed by goniometry in lifting the leg with the knee extended test, had as a parameter to stop the test the pain reported by participants during the elevation of the leg. Testing one-way ANOVA and post hoc Tukey test IC 95\% showed a decrease ( $p$ $<0.05$ ) from the ninth session (Figure 2 ). This value was compared with the initial value before starting the treatment. Comparing the value of the range of motion of the hip on the initial assessment and the last day of service was meant the difference $(p<0.001)$.

The evaluation of the neural damage, through the Slump test, assessed the range of motion of knee extension, which is one of steps for making the neural tension test. In this test the knee should extend fully, leaving $90^{\circ}$ and heading toward $0^{\circ}$. Testing one-way ANOVA and post hoc Tukey test CI 95\% showed that there was a numerical gain, but not statistically significant between study participants (Figure 3 ).

The results concerning the range of motion of the trunk assessed by testing the third finger of the right hand to the ground showed a numerical increase, but not statistically significant (Figure 4).

The Student t test $95 \%$ CI significance $p<0.05$ for paravertebral dynamic force in the extensor endurance test showed a significant increase statistically with $\mathrm{p}=$ 0.0277 (Figure 5).

The Student test $95 \% \mathrm{CI}$ and significance $\mathrm{p}<0.05$ for abdominal strength in the dynamic test abdominal strength showed a numerical gain, but these results were not statistically significant $p=0.1877$ for sample (Figure 6).

\section{DISCUSSION}

We attribute this improvement in pain to the effects that pompage techniques, neural mobilization, GPR and segmental stabilization can cause the structures related to this symptom. Techniques pompages act on the fascia and releasing blocks liquid stasis. This is exerted on the entire segment mobilizing the fascia widely as possible, promoting muscle relaxation. ${ }^{(9)}$

Study using the technique of neural mobilization for a period of four weeks, three days per week, for twenty minutes and applying analogue scale of pain in patients with lumbar disc herniation showed a decrease in pain intensity and functional disability. However even these were nociceptive impairment in performing some activities. (3) The intensity of pain was evaluated in this study with the same rating scale and there was also a significant decrease in pain.

The postures used in the GPR method cause physiological phenomena that lead to regain range of motion, promoting stretching of shortened muscles and especially the pain relief.(10) In the present work using a set of manual therapy techniques including GPR partici-

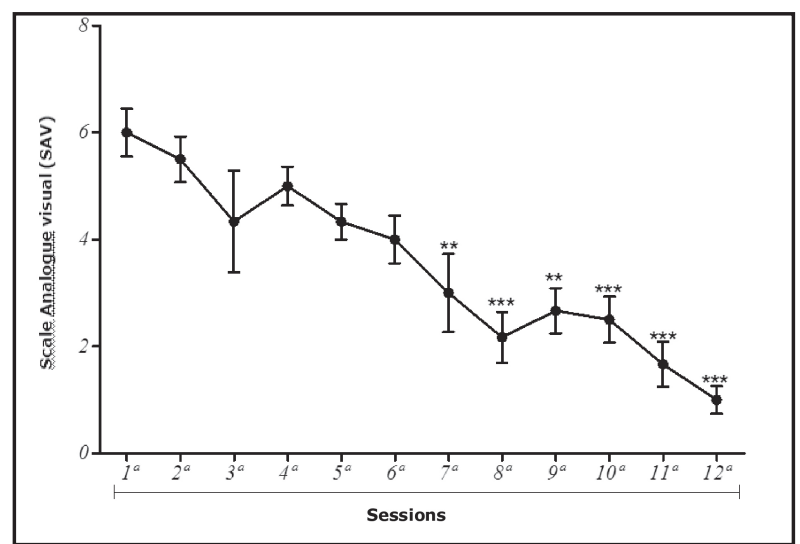

Figure 1. Assessment of changes in visual Analog Scale for pain in different treatment sessions. $* * p<0,01 ; * * * p<0,001$.

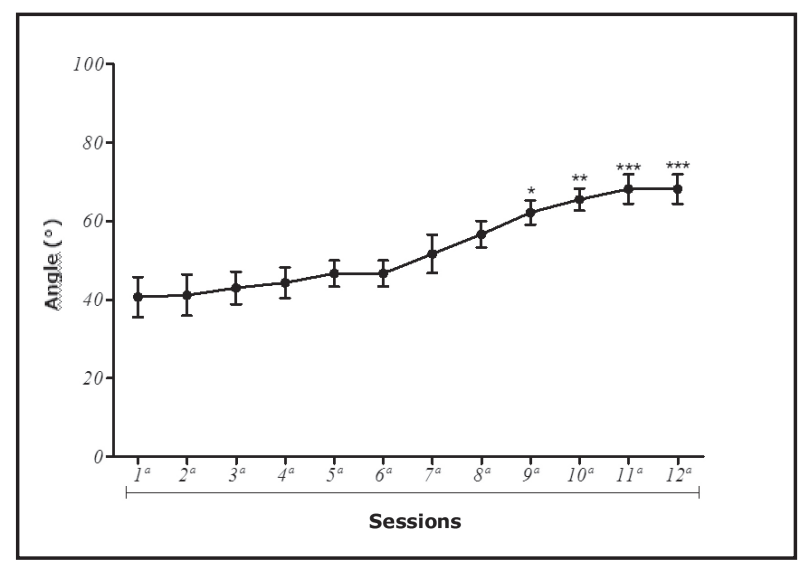

Figure 2. Assessment of changes goniometry hip flexion in the leg raising test with extended treatment sessions in different $\mathrm{kn}$ ee. $* p<0,05 ; * * p<0,01 ; * * * p<0,001$.

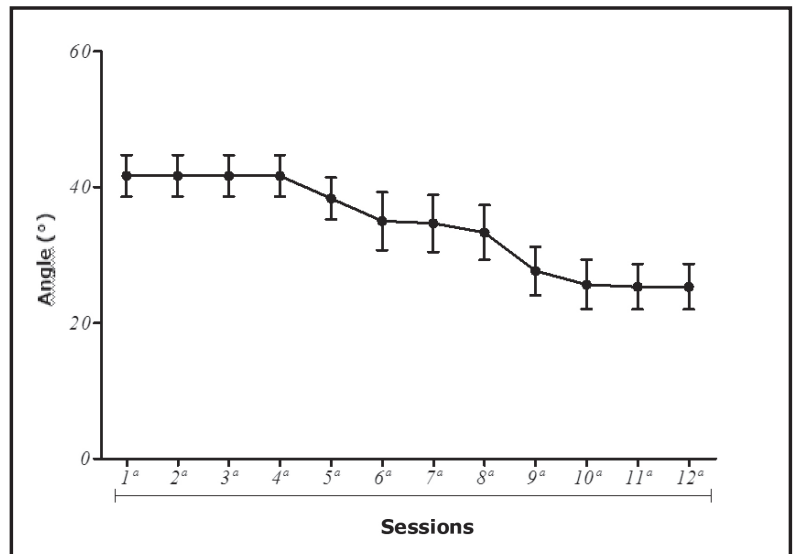

Figure 3. Evaluation of variations in goniometric knee for patients in diferente treatment sessions.

pants reached statistically significant results in relation to pain. This improvement of pain symptoms was also observed in patients with disc protrusion can is associated with improved mobility of tissues related to the spine and the muscles that to be with their restricted flexibility can contribute to compressive processes of neural structures, thus contributing for pain symptoms. 


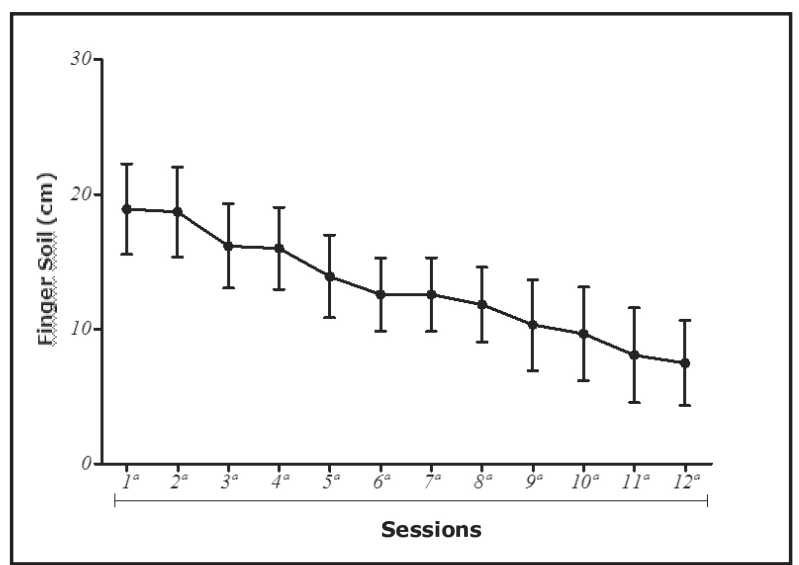

Figure 4. Evaluation of variations in distance measurements in the test finger to the ground of the patients in the different treatment sessions.

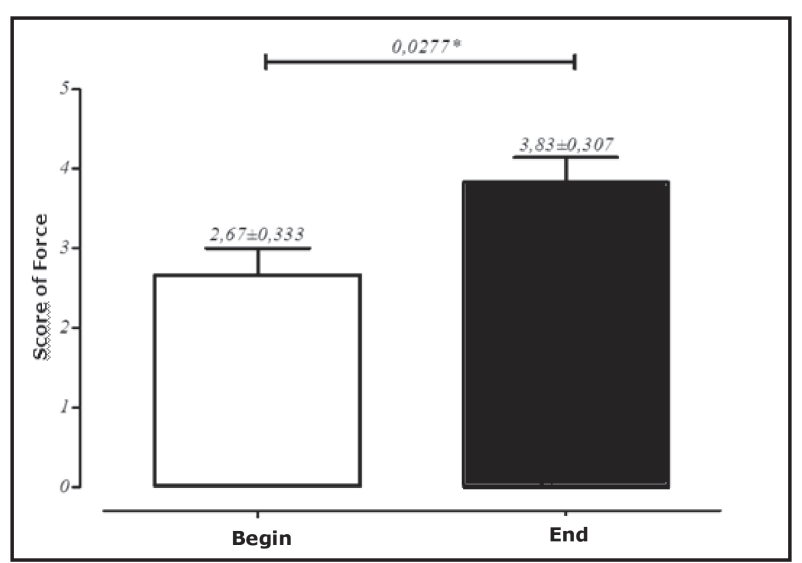

Figure 5. Test the strength paravertebral before and after sessions of physiotherapy treatment of patients. ${ }^{*} p=0,0277$

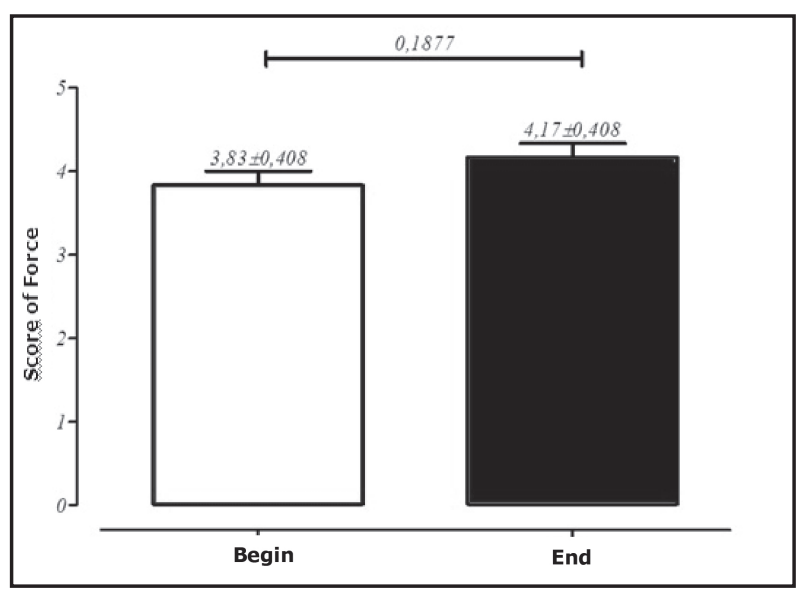

Figure 6. Abdminal strength test before and after sessions of physiotherapy treatment of patients.

Previous reseaches with the Global Postural Reeducation method in individuals with low back pain demonstrated a reduction in Visual Analog Scale (VAS) of pain of $85.7 \%$ and showed a reduction in functional disability Roland Morris questionnaire (RMQ) of $77.1 \%$. The survey consisted of 35 participants aged between 18 and 75 years. Eve in the median level of back pain reported by the participants before the start of treatment was at the end of six and ten sessions was one. RMQ on this score was four at the beginning of treatment and at the end of it was a. These results were statistically significant and characterized a significant clinical improvement as the variables of pain and functional disability after completion of GPR. ${ }^{(6)}$

A survey consisting of 12 young adult participants in the physical therapy course of Universidade Estadual do Centro-Oeste (Unicentro) with nonspecific chronic low back pain showed improvement in pain and functional capacity through the contraction of the deep muscles of the trunk and transversus abdominis after six weeks of segmental stabilization exercises. In this study there was a reduction of pain by VAS in all participants. ${ }^{(11)}$

The test lifting of the leg with the knee extended performs a hip flexion and at this time applies a voltage on the sciatic nerve. This nerve when committed in the lumbar disc protrusion may cause a decrease in the amplitude of this motion test. Therefore it is believed that the evaluation of the test goniometer hip can be a parameter to show the improvement of nerve involvement since this change will occur with decreasing voltage neural tissue of the sciatic nerve.

Studies conducted using the technique of neural mobilization revealed an increase in range of motion of the hip and half of the volunteers reached near normal values considered for ROM in hip flexion $\left(80^{\circ}\right)$ these values were compared before and after treatment using the neural mobilization. (12) Regarding the range of motion of the hip, in this study the final results were significant ( $p<0.001)$, one of the participants showed hip range of motion corresponding to $20^{\circ}$ before starting treatment and after this obtained hip range of motion corresponding to $75^{\circ}$, approaching normal values. The other participants showed similar results of normality.

The slump test is a test used to evaluate the neural damage by placing the neural strain, and in this study the parameter for stopping the test was shown by the participants pain following knee extension. Therefore, when evaluating joint motion of the knee was examined whether there was improvement during the treatment, so as to relate this change with a probable decrease the tension on the neural tissue during testing.

The neural mobilization aims to restore movement and elasticity of the affected structure providing a return to their daily functions. ${ }^{(13)}$ This technique promotes easily in making the motion and the elasticity of the nervous system, creating and perfecting their normal functions, with consequent increase in range of motion. ${ }^{(14)}$ In the present study the range of motion improved significantly in lifting the leg with the knee extended test, but the same was not observed in the Slump test, a gain in range of motion but was not significant.

The difference of the results of neural tension tes- 
ting in this case can be attributed to the fact that in the leg raising test with the knee extended neural tension is greater in the lower limb and the participant is supine. While the Slump test neural tension focuses on the neural structures of the most intensely column because the participant bends the trunk forward and is sitting, which causes increased pressure on the intervertebral disc.

The pompage techniques, neural mobilization and GPR were used in this study, and one of the indications of these techniques is to improve flexibility, which would lead to increased range of motion. The chosen research techniques had a performance on the flexibility of the tissues of the spine region and the posterior region of the lower limbs. Despite the possibility of promoting satisfactory effect in improving the flexibility of the trunk, analyzed by the third finger to the soil test, this was not observed in the present study.

Studies conducted using other techniques associated with fibromyalgia patients in 10 treatment sessions to pompage showed improvement in sleep quality, decreased positivity of Tender Points (down 55\%), improving muscle flexibility, posture and well-being general patient. ${ }^{(15)}$

Studies carried out using the technique of neural mobilization and stretching program for individuals with chronic low back pain showed significant results in relation to neural mobilization program in the pain reduction on the VAS, and marked improvement of flexibility when analyzed by the flexibility finger away-solo is also effective in increasing the flexibility of the posterior muscle chain, both in the evaluation of finger-ground distance for the evaluation of the angle of knee flexion. The interventions were carried out at least twice a week, lasting about 30 minutes each, totaling 20 sessions. ${ }^{(13)}$ In the present study also achieved a reduction in pain VAS scale.

The foot posture of leaning forward promotes stretching of the posterior muscles of the lower limbs. This it is a precious position in pathologies such as low back pain with or without disc disease and sacroiliac injuries. (16) In this study the posture of leaning forward foot was used in participants with the goal of increasing the range of motion of the trunk. All participants were able to gain a numerical approaching the third finger of the right hand to the ground, and two subjects reached zero, which indicates an improvement in range of motion of the trunk compared to the original value before performing the techniques.

The preliminary results showed that the standing posture of the GPR with the previous slope method, basketball players, particularly promotes stretching of the paravertebral muscles and hamstrings, thereby facilitating the decrease of the angle of the hip joint by increasing the flexibility. ${ }^{(17)}$ In study the results were different, but it is important to note that the sample used in the research cited previously were athletes without disc protrusion, so the fact that an impairment may have influenced the length of stay in posture. For the stretching of a muscle and its connective tissue is directly proportional to the time of traction. ${ }^{(18)}$

In a survey of a sample of 30 women were randomly divided into three groups of 10 subjects each: the global group did stretching technique by GPR; the target group did stretching segment and the control group did not stretch, the study aimed to compare the effect of GPR and elongation segmental gain flexibility, muscle strength and ROM. Significant gain was observed in all variables. ${ }^{(19)}$ In relation to the flexibility the result was different, but in this study there was also a significant increase in muscle strength of the paraspinal musculature.

The paraspinal muscles are located in the posterior region of the spine in a surface layer, in the same region are the multifidus muscles in a deep layer, these muscles act to stabilize the spine by techniques such as segmental stabilization that will promote the strengthening of these muscles. ${ }^{(20)}$ The present study showed an improvement in paraspinal and abdominal muscle strength after making the calls, but it was only a significant increase to the paravertebral strength. This could be attributed to the fact that the paraspinal muscles were more needed for contraction, since both were worked in the posture of the GPR, as in segmental stabilization exercises, abdominal muscles have been worked only in segmental stabilization exercises.

The segmental stabilization is a method of strengthening based on awareness of muscle contraction, the resistance training of the lumbar stabilizers and proprioceptive stimulation. ${ }^{(21)}$ The present study showed significant results in relation to the paravertebral gain strength, but in relation to abdominal strength was only a numerical gain.

The lumbar segmental stabilization does not put the structure injured at risk, especially at the beginning of rehabilitation, reducing the external load and keeping the spine in neutral position. The exercises are subtle, specific and precise, reducing the chance of pain or reflex inhibition. For maximum benefit, must be repeated several times or as needed. The progression can be performed in several stages. The series can be progressed from low loads with minimal weight to more functional positions with gradual increase in load. ${ }^{(22)}$

In a research conducted on the segmental stabilization exercises six patients suffering from Herniated Lumbar Disc (HDL) were analyzed. Four of the subjects had localized degeneration at L4/L5 (66.7\%) and two in L5/S1 (33.3\%). All participants showed poor contraction of the lumbar stabilizers and pain (radiating or localized). The treatment with the technique of stabilizing segment consisted of 15 sessions, and three times a 
week, and remeasured at the end of the protocol. The technique was effective in increasing the tropism of the multifidus, improves the effective capacity of voluntary contraction of the lumbar stabilizers and the pain reduction. ${ }^{(26)}$

These exercise programs that aim to lumbar stabilization aim to improve neuromuscular control, strength and endurance of the trunk and pelvic floor muscles, which are recruited to important functions of Dynamic Stability in column. ${ }^{(23)}$

Study with 18 volunteers using the program segmental stabilization in low back pain associated with degenerative-mechanical to a plan postural education held 18 meetings had better scores on the research results in the areas of pain, limitations in physical aspects and functional capacity. ${ }^{(24)}$

Study comprised 20 volunteers with nonspecific chronic low back pain, divided into two groups: a control group, which used the Pilates method and the experimental group, which used the Pilates method asso- ciated with segmental stabilization during 16 treatment sessions, twice a week. Showed significant results for reducing pain and functional disability. ${ }^{(25)}$

\section{CONCLUSION}

The present research studied the effects of manual therapy techniques that are indicated in the treatment of lumbar disc protrusion. With the results it is concluded that the realization of pompage techniques, neural mobilization, GPR and segmental stabilization promote positive effect on the rehabilitation of these patients, as it improves pain, reduces neural impairment observed in the leg raising test with the knee extended, and increases the strength of the paravertebral muscles. However was not observed improvement of neural commitment by Slump test, abdominal strength and range of motion of the trunk. Importantly, the set was the realization of the techniques that led to these results, so we can not say that the use of these techniques alone would achieve significant results as in our study.

\section{REFERENCES}

1. Negrelli WF. Hérnia discal: Procedimentos de tratamento. Acta Ortop Bras. 2001;9(4):39-45.

2. Vialle LR, Vialle EN, Henao JES. Hérnia discal lombar. Rev Bras Ortop. 2010;45(1):17-22.

3. Monnerat E, Pereira SJ. A Influência da técnica de mobilização na dor e incapacidade funcional da hérnia de disco lombar: estudo de caso. Rev Ter Man. 2010;8(35):66-69.

4. Sanches ML, Luz R, Oliveira J, Biasotto-Gonzalez DA, Mesquita-Ferrari RA. Pompage no tratamento da síndrome de fibromialgia-estudo piloto. Rev Ter Man. 2008;6(28):347-352.

5. Butler DS. Mobilização do sistema nervoso. São Paulo: Manole; 2003.

6. Cloris REM, Canto LFO, Maraísa NT, Fátima CMG. Estudo da eficácia do método de Reeducação Postural Global em indivíduos com dor lombar com relação a dor e incapacidade funcional. Ter Man. 2010; 8(38):292-297.

7. O'Sullivan P. Instabilidade segmentar lombar: apresentação clinica e exercícios estabilizadores específicos. Man Ther. 2000;5(1):2-12.

8. Magee DJ. Avaliação Musculoesquelética. 3ed. São Paulo: Manole, 2005.

9. Bienfait M. Estudo e tratamento do esqueleto fibroso: Fáscia e pompages. 4.ed. São Paulo: Summus, 1995.

10. Heredia EP, Rodrigues FF. O tratamento de pacientes com fibrose epidural pela reeducação postural global- RPG. Rev Bras Neurol. 2008;44(3):19-26.

11. Pereira NT, Ferreira BAL, Pereira WM. Efetividade de exercícios de estabilização segmentar sobre a dor lombar crônica mecânico-postural. Fisioter Mov. 2010;23(4):605-614.

12. Santos CF, Domingos CA. Avaliação pré e pós- mobilização neural para ganho de ADM em flexão do quadril por meio do alongamento dos isquiostibiais. Conscientiae Saúde. 2008;7(4):487-495.

13. Machado GF, Bigolin SE. Estudo comparativo de casos entre a mobilização neural e um programa de alongamento muscular em lombálgicos crônicos. Fisioter Mov. 2010;23(4):545-554.

14. Lopes RSD, Barja PR, Matos LKBL, Delmondes FF, Lopes PFD, Silva KAS, et al. Influência do alongamento e da mobilização neural sobre a força do músculo quadríceps. Conscientiae Saúde. 2010; 9(4): 603-609.

15. Rocha MO, Oliveira RA, Oliveira J, Mesquita RA. Hidroterapia, pompage e alongamento no tratamento da fibromialgia - relato de caso. Fisioter em Mov. 2006;19(2):49-55.

16. Souchard P. RPG: Reeducação postural global o método. Rio de Janeiro: Elsevier Masson, 2011.

17. Borges BLA. Flexibilidade de atletas de basquetebol submetidos à postura "em pé com inclinação anterior" do método de reeducação postural global (RPG). Rev Bras Ci e Mov.2006;14(4):39-46.

18. Moreno MA, Catai AM, Teodori RM, Borges BLA, Cesar MC, Silva E. Efeito de um programa de alongamento muscular pelo método de reeducação postural global sobre a força muscular respiratória e a mobilidade toracoabdominal de homens jovens sedentários. J Bras Pneumol. 2007;33(6):679-686. 
19. Rosário JLP, Sousa A, Cabral CMN, João SMA, Marques AP. Reeducação postural global e alongamento estático segmentar na melhora da flexibilidade, força muscular e amplitude de movimento: um estudo comparativo. Rev Fisioter e pesq. 2008;15(1):1-15.

20. Soares AV, Lima WC, Borges Júnior NG. Controle do tronco: Implicações na lombalgia. Arq Cienc Saúde Unipar. $2003 ; 7(3): 283-289$.

21. Siqueira GR, Silva GAP. Alterações posturais da coluna e instabilidade lombar no indivíduo obeso: uma revisão de literatura. Fisioter Mov. 2011;24(3): 557-566.

22. França FJR, Burke TN, Claret DC, Marques AP. Estabilização segmentar da coluna lombar nas lombalgias: uma revisão bibliográfica e um programa de exercícios. Fisioter e Pesq. 2008;15(2):200-6.

23. Standaert $\mathrm{C}$, Herring, SA. Expert opinion and contraversies in musculoskeletal and sports medicine: core stabilization as a treatment for low back pain. Arch Phys Med Rehabil. 2007;88(12):1734-6.

24. Moser AD, Scharan KO, Pereira PA, Passini C. Escola da coluna associada a estabilizacão segmentar na lombalgia mecânico-degenerativa. Ter Man. 2012;10(50):364-373.

25. Silva DKB, Murata E, Freitas, CD. Comparação do método pilates com e sem a estabilização segmentar na dor lombar crônica. Ter Man. 2013;11(51):90-94.

26. Siqueira GR, Alencar GG, Oliveira NK, Leite FNTS. A eficácia da estabilização segmentar vertebral no aumento do trofismo dos multífidos e melhora da dor em portadores de hérnia discal lombar. R. Bras. Ci. e Mov. 2014; 22(1): 81-91. 